\title{
Whale Shark in The Development of Geopark and Sustainable Tourism in Gorontalo, Indonesia
}

Umar Adisubroto ${ }^{\bullet}$ and Togu S. Pardede ${ }^{2}$

Corresponding author.・Email: adisubroto.umar@gmail.com

Submitted: 2021-12-10| Accepted: 2021-12-13| Published: December $31^{\text {st }} 2021$

\begin{abstract}
The whale shark (Rhincodon typus, Hiu Paus), the world's most significant type of fish/mammal, appears in Indonesia, Botubarani, and Gorontalo province. This province is actively developing geoparks that are currently still aspiring geopark status and tourism and making whale sharks its icon. Our paper studies the development of whale sharks as a marker of the area's biodiversity to promote it as a more common activity in Indonesia, where whale sharks can be found. We support strategic ideas for the development of whale sharks and formulate several recommendations for geotourism activities where whale sharks are icons.
\end{abstract}

Keywords: whale shark; Gorontalo; geopark; biodiversity; conservation; geotourism.

${ }^{1}$ Biodiversity Analyst and Staff Member, Task Force of National Action Plan for Geopark Development, Bappenas.

${ }^{2}$ Senior Planner and Head, Task Force of National Action Plan for Geopark Development, Bappenas. 


\section{Introduction}

The Whale shark (Rhincodon typus, Hiu Paus in Indonesian) is the world's most significant type of fish/mammals and marine biota (up to 20 meters long), an eater of plankton and small fish/shrimp, moving slowly, living, and crossing tropical oceans including in some waters in Indonesia. One place in Indonesia where the whale shark often appears is on the coast of Botubarani, in the Gulf of Tomini area, Gorontalo province (Nugroho, 2020; BPSPL Makassar, 2017).

The whale shark is a rare species protected by international law and Indonesian national law. Nevertheless, the nature of the whale shark that is "friendly" (does not attack humans) and its presence in easily accessible places such as Botubarani beach makes it an exciting attraction for tourism activities. However, special interest tourism is very rare in Indonesia, even in the world.

Gorontalo province, one of the five provinces on the island of Sulawesi, places tourism development as one of its development priority programs (The Medium Terms of Development Planning, Province of Gorontalo, 2017-2022). The province of Gorontalo is in the bio-region in the Wallacea region, which has a faunal flora with high endemicity, a unique geological formation process, and cultural wealth that has been maintained until now. The Provincial Government realizes its uniqueness by initiating the development of a sustainable Geopark with its current status as an "Aspiring Geopark." 1 The sustainability aspect will lift geo-bio-culture diversity for the region's conservation efforts juxtaposed with the education and welfare of local communities through tourism. Both the tourism development program of Gorontalo province and the geopark development program conducted by Gorontalo province make the land area of Botubarani waters and whale sharks an icons/tourist attraction and a geo-site in the Geopark area.

This paper links whale sharks in the Botubarani park with tourism and the development of the Gorontalo Geopark. In particular, some matters need to be considered regarding the management of whale sharks to be able to make economic contributions from tourism activities and conservation aspects that must be done to ensure the survival of the whale sharks. Furthermore, this paper intends to learn lessons from the management of whale sharks on Botubarani beach to be applied elsewhere in Indonesia that potentially become a whale shark track/tourism in Indonesia.

The paper is largely based on literature studies, with information gathered on-site from related government offices. Limited surveys were conducted directly on Botubarani Beach, Gorontalo.

This paper is structured as follows. Chapter One provides an introduction and an overview of the paper. Chapter Two describes the whale shark and its presence in Indonesia. Chapter Three reveals the basic concepts of geopark development, particularly those relating to biodiversity. In Chapter Four, we suggest some conservation principles and geo-tourism development based on whale sharks. Chapter Five concludes the paper and proposes some recommendations.

\section{Facts about whale sharks}

Morphologically, whale sharks are the largest fish globally that can grow up to 20 meters long and weigh 34 tons. Whale sharks have a broad head and a scab, a large mouth with a gill pair, and a relatively large dorsal fin. In addition to a vast body, whale sharks are easily recognized because of their gray and white spots body unique to each whale shark

\footnotetext{
${ }^{1}$ Geopark development status can be categorized into three levels: (1) Aspiring Geopark, (2) National Geopark, and (3) UNESCO Global Geopark.
} 
(BPSPL Makassar, 2017). ${ }^{2}$ Whale sharks belong to the order of Orectolobiformes (carpet sharks) and have characteristics similar to other carpet sharks such as nurse sharks and starfruit/zebra sharks. ${ }^{3}$

Figure 1. shows the sighting of a whale shark.

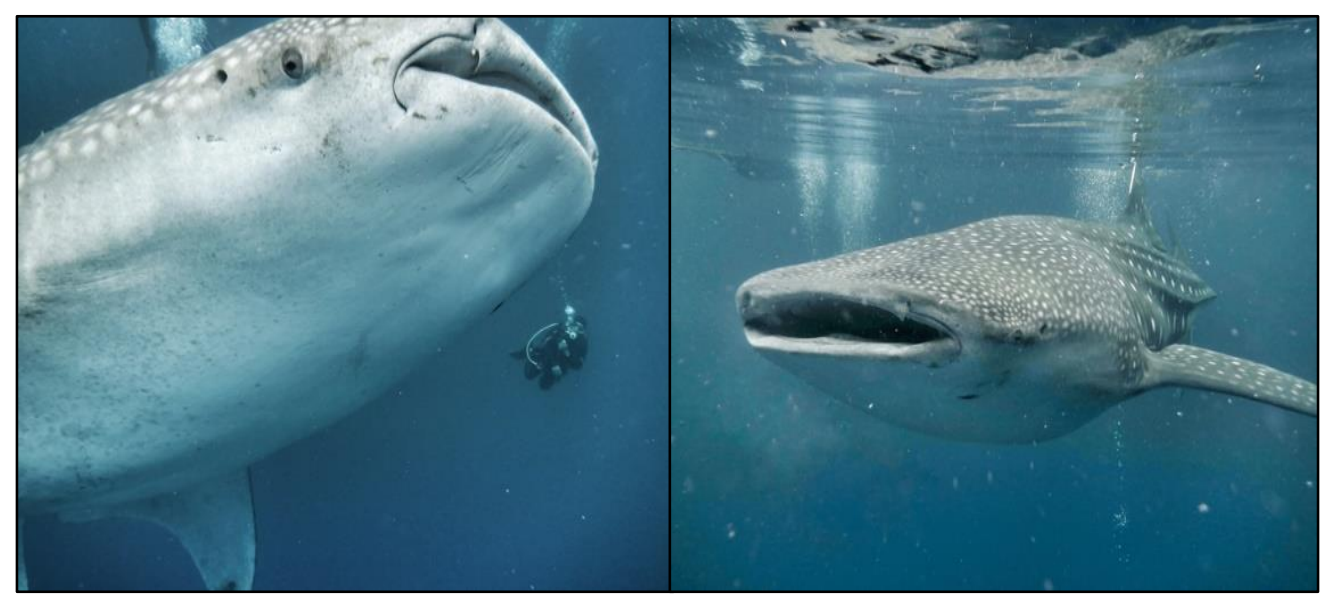

Figure 1. Whale Shark

Source: Photo by Umar Adisubroto (2020)

The name of "Whale Shark" because it contains the words "Shark" and "Whale" sometimes causes misunderstandings. The word "whale" actually refers to baleen whales, large marine mammals that have baleen (brushes) in their mouths that serve as small prey catchers, such as shrimp (krill). Unlike baleen whales that are mammals, whale sharks belong to the type of fish, breathing with gills, as many as five pieces on the right-left side of the head. The gill also serves as a filter/prey catcher and baleen in baleen whales.

In the world, whale sharks are found in tropical oceanic seas with warm waters, including in Indonesia and Australia. However, in contrast to large sharks that prefer to live in deep waters (benthic), whale sharks are pelagic (like at sea level) with sea surface temperatures (not far from the beach) around 21-30 degrees Celsius and which contain much plankton. The world's whale shark population, including its reproductive process, is not widely understood yet.

In Indonesia, several locations have been identified as places of life and the emergence of whale sharks. As shown in Table 1, the location is quite widespread in various regions in Indonesia, ranging from Riau Islands province, East Kalimantan, East Nusa Tenggara, to Papua. The same table also shows the number of whale sharks observed from several observations or research that have been done in Indonesian waters.

\footnotetext{
${ }^{2}$ Badan Pengelolaan Sumberdaya Pesisir dan Laut Makassar, 2017. Hiu Paus di Pantai Botubarani, Gorontalo. ${ }^{3}$ Ibid.
} 
Umar Adisubroto and Togu S. Pardede

Table 1. Whale sharks observed in some Indonesian waters

\begin{tabular}{|l|l|l|l|}
\hline Territorial Waters & $\begin{array}{l}\text { Number } \\
\text { observed (tail) }\end{array}$ & $\begin{array}{l}\text { Year of } \\
\text { observation }\end{array}$ & Source \\
\hline $\begin{array}{l}\text { Cenderawasih Bay } \\
\text { (Papua) }\end{array}$ & 131 & $2010-2016$ & Tania et. al. (2016) \\
\hline $\begin{array}{l}\text { Kaimana } \\
\text { (West Papua) }\end{array}$ & 20 & $2014-2015$ & $\begin{array}{l}\text { Hasan \& Sianipar } \\
\text { (2019) }\end{array}$ \\
\hline $\begin{array}{l}\text { Sawu Sea } \\
\text { (East } \\
\text { NusaTenggara) }\end{array}$ & 7 & 2016 & Putra \& Lewis (2017) \\
\hline $\begin{array}{l}\text { Talisayan } \\
\text { (East Kalimantan) }\end{array}$ & 36 & $2014-2017$ & Himawan (2017) \\
\hline $\begin{array}{l}\text { Botubarani } \\
\text { (Gorontalo) }\end{array}$ & 20 & 2017 & Himawan (2017) \\
\hline $\begin{array}{l}\text { Probolinggo } \\
\text { (EastJava) }\end{array}$ & 28 & 2016 & Himawan (2017) \\
\hline $\begin{array}{l}\text { Anambas } \\
\text { (Riau Islands) }\end{array}$ & 11 & $\mathbf{2 5 3}$ & Himawan et. al. (2017) \\
\hline T o t an 1 & 2016 & (2016 & \\
\hline
\end{tabular}

Source: Budi Nugroho et al., 2020, Indonesian Fisheries Policy Journal Vol. 12 No. 1, March 2020

In terms of tourism, although the number of whale sharks that have been observed on Botubarani beach is slightly lesser compared to those observed in Cenderawasih Bay National Park, Botubarani has an advantage over other waters in Indonesia visited by whale sharks because of its location that is easily reached by residents/tourists. ${ }^{4}$ Because of the ease of access, the total costs needed to watch whale sharks in Botubarani are relatively cheap compared to, for example, the Cenderawasih Bay National Park area or Anambas waters in Riau Islands. Besides, whale sharks on Botubarani beach are more frequent than that of other waters. In addition to the usual presence of small fish carried out by fishing activities around the beach, the frequent presence happens because there is a Vaname shrimp processing plant on Botubarani beach whose waste is used in the area. ${ }^{5}$

Whale sharks are a protected species. Since 2002, whale sharks have been included in Appendix II of the Convention on International Trade in Endangered Species of Wild Fauna and Flora (CITES). Since 2016 whale sharks have been categorized as endangered species by the International Union for Conservation of Nature (IUCN). Through the Decree of the Minister of Marine Affairs and Fisheries of the Republic of Indonesia Number 18 of 2013, the Government of Indonesia has designated whale sharks as a species that must be fully protected.

\footnotetext{
${ }^{4}$ Botubarani Village directly faces Tomini Bay, included in Kabilabone Subdistrict, Bone Bolango Regency, Gorontalo Province.

${ }^{5}$ Opcit.
} 


\section{Whale Shark and supporting Geopark activities}

\subsection{Geopark Development Policy in Indonesia}

Geopark is "an integrated area that is running and sustainably utilizing geological heritage, as well as improving the economic well-being of the surrounding population" (Keever, 2015). It was originally intended to protect the geological heritage in European countries. UNESCO (United Nations Educational, Scientific and Cultural Organization) in 2004 defined Geopark as "an area that has prominent geological elements - including the archaeological, ecological and cultural values contained in it - in which local communities are invited to take part in protecting and enhancing the functioning of the Earth's heritage."

Geopark is a relatively new concept, introduced by EGN (Europe Geopark Network) in2001, then adopted and facilitated by UNESCO, among others, by forming GGN (Global Geopark Network) in 2004. According to UNESCO's GGN (2004), the purpose of the Geopark is to benefit, excavate, appreciate and develop geological heritage. It is also mentioned that the requirements to become a Geopark, the region must possess 3 (three) main elements, namely Geo-diversity (geological diversity), Bio-diversity, and Cultural diversity). Since November 17, 2015, at the $38^{\text {th }}$ conference, UNESCO made Geopark an official program under the International Geoscience and Geoparks Programme under the name The UNESCO Global Geopark. Unesco's 195 member states agreed to approve the establishment of the program to recognize the importance of managing valuable geological sites and landscapes holistically.

Geoparks can be divided into three rankings/categories, namely: (1) Aspiring Geopark,(2)National Geopark, and (3) UNESCO Global Geopark. The requirements to become a UNESCO Global Geopark include that the Geopark is already a National Geopark in the country, has dedicated management, master plan with clear territorial boundaries (set by the government), the region is wide enough to conduct local economic development, and in it, there has been a minimum of three activities that take place, namely conservation, education, and tourism.

Indonesia is quite active in developing its Geopark. Currently, in Indonesia, there are 6 UGG (UNESCO Global Geopark) from 169 UGG globally spread across 44 countries. In addition, Indonesia also has 13 National Geoparks (August 2021) and several candidates (aspiring) who are working to improve their status. Table 2 shows UNESCO Global Geopark and National Geopark located in Indonesia.

Table 2. Geoparks in Indonesia

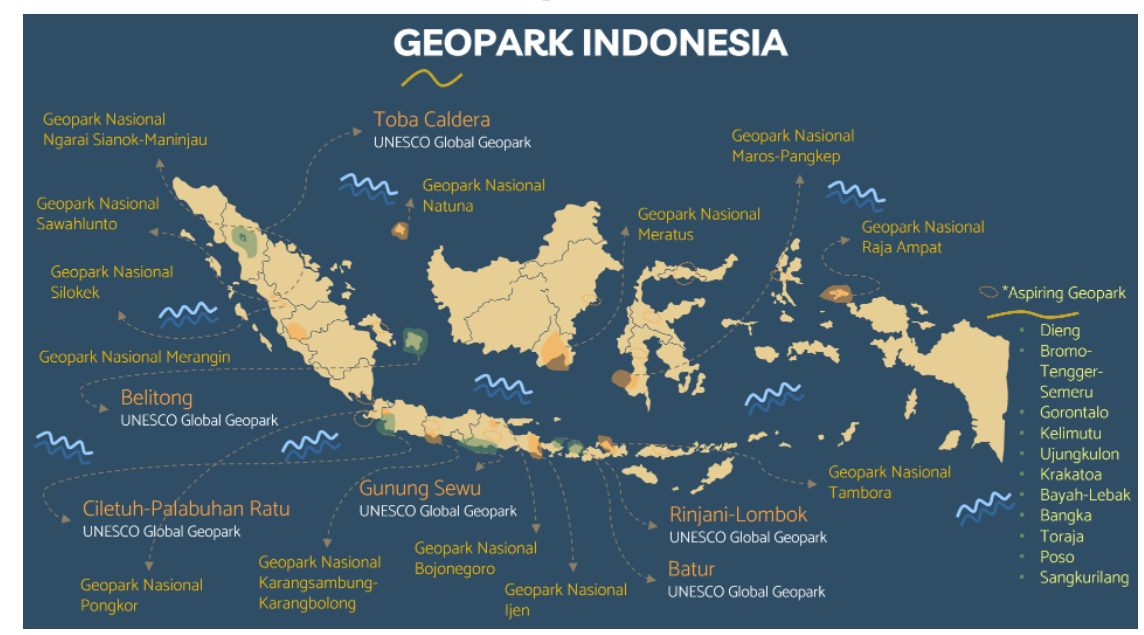


Umar Adisubroto and Togu S. Pardede

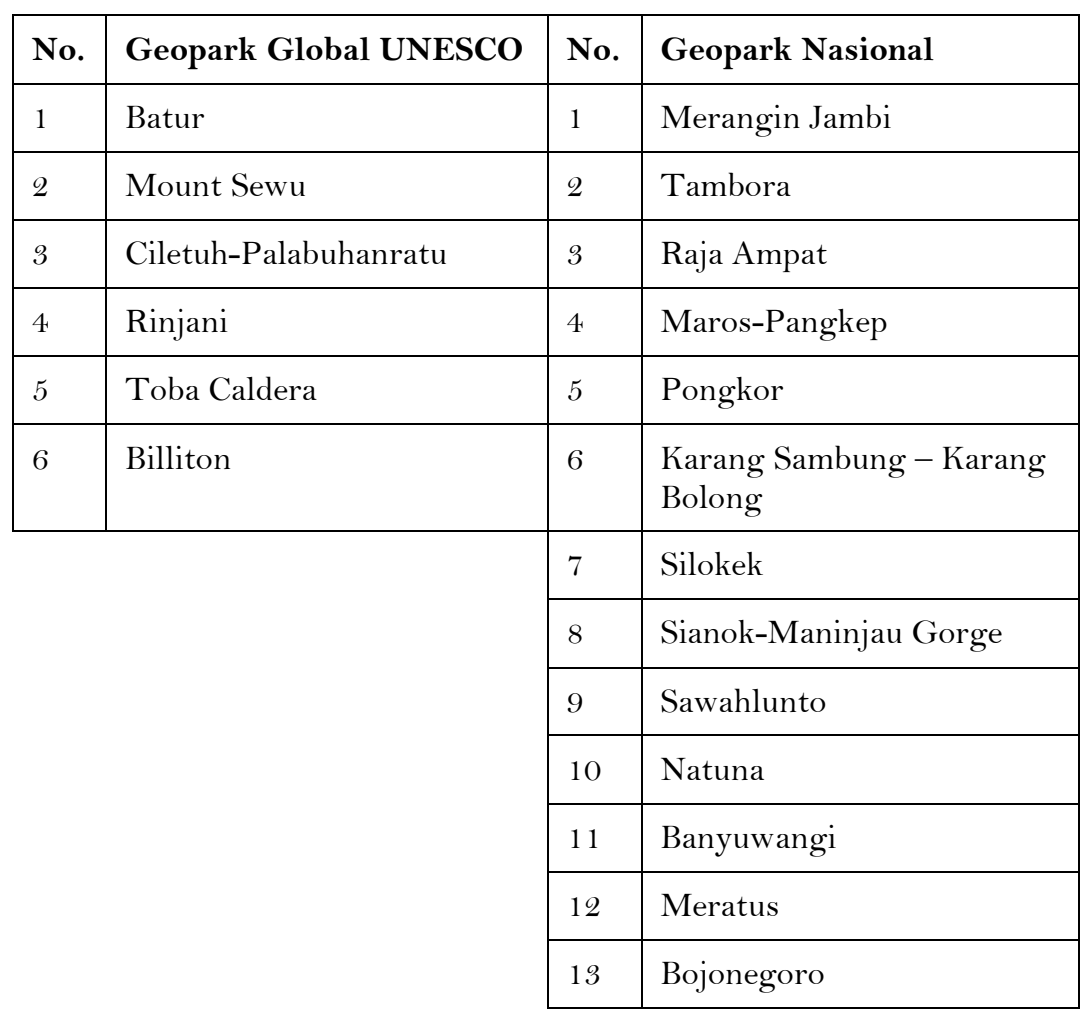

Source: Bappenas, Task Force of National Action Plan for Geopark Development, 2021

As a regulatory framework, the President of the Republic of Indonesia has issued Presidential Regulation No. 9 of 2019 on the Development of Geopark to support geopark activities. As its derivation, the Minister of Energy and Mineral Resources issued Regulation Number 01 of 2020 regarding Determination of Geological Heritage, while the Minister of Tourism issued Minister Regulation No. 02 of 2020 on The Development of Geoparks as Tourism Destination. In addition, the National Development Planning Minister Regulation/Head of National Development Planning Agency issued the Minister Regulation No. 15 of 2020 on Indonesia's Geoparks Development Action Plan 2021-2025, integrating it with SDGs (Sustainable Development Goals). Indonesia has also established the National Committee of Indonesian Geopark (KNG) and Indonesia Geopark Network in terms of the institutional framework. The Ministry of Development Planning/Bappenas is currently reviewing and preparing a Geopark development funding framework to provide certainty of access to financing in geopark management.

\subsection{Development of Gorontalo Aspiring Geopark}

Gorontalo Geopark contains rich geological, biological, and cultural diversity (Kurniawan, 2017). Gorontalo province has many locations that show great geological diversity in lakes, bays, beaches, small islands, hills, waterfalls, and hot springs. However, many are unexplored, studied, or not yet established to become geo-tourism activities. To improve the status of Gorontalo Geopark from Aspiring Geopark to a National Geopark, the Gorontalo government has proposed some 26 geological heritage to the central government to be assessed. ${ }^{6}$

\footnotetext{
${ }^{6}$ Source: https://infopublik.id/kategori/nusantara/505614/gorontalo-usulkan-26-warisan-geologi-ke-badangeologi-kementerian-esdm. Accessed July 12, 2021.
} 
In terms of biodiversity, Gorontalo has a variety of flora and fauna. In Gorontalo, there is Bogani Nani Wartabone National Park which preserves the rich flora and fauna of Sulawesi. In this National Park, there are various species of fauna such as mammals (24 species), birds (125 species), reptiles (11 species), amphibians (2 species), butterflies (38 species), beetles (200 species), and fishes (19 species). Among those protected are maleo birds, yaki monkeys, Bone bat, dwarf cuscus, and bear cuscus. (Kurniawan, 2017).

The whale shark is a biodiversity object highlighted in the construction of The Gorontalo Geopark and will be used as a tourism object by the Gorontalo government. This is thanks to the unique shape and nature of the whale shark and its not much presence in Indonesia.

\section{Principles of conservation and development of geo-tourism based on Whale Sharks}

The interaction of whale sharks with humans on Botubarani beach is the most beautiful in Indonesia. Some of the factors that affect it are:

(i) Easy and cheap access to Botubarani Beach from the center of Gorontalo City,

(ii) Very close to the appearance of Whale Sharks from the shore,

(iii) Botubarani Beach is very clear, whale sharks can be seen clearly from the surface as well as in the water, and

(iv) The frequent appearance of whale sharks, can be from morning to evening, even at night. ${ }^{7}$ Since 2016, tourists visiting Botubarani and watching whale shark attractions from boats have reached tens of thousands of people, not including for snorkeling and diving. ${ }^{8}$

The construction of a Geopark should bring economic benefits to the surrounding community. Learning from the case of Botubarani Whale Shark and literature, tourism development / geo-tourism needs to start by identifying stakeholders, to be able to collaborate to succeed in tourism development goals in the area. Generally, the stakeholders are elements of the society as well as the government. In the development of Botubarani whale shark geo-tourism, the stakeholders are Tourism Office, Marine and Fisheries Service, Energy and Mining Service (Government element), BPSPL Makassar, Gorontalo State University, Gorontalo State University (Research-College), Indonesian Navy in Gorontalo, Gorontalo Police Water Police (Security), Tourism Awareness Group, Fishermen's Group, NGO (Community), Indonesia-Gorontalo Travel Entrepreneurs Association, Gorontalo Tour Guide (Business).

The Tourist Conscious Group is very important to develop because they are direct/major actors in the tourism activities of the whale sharks. They were recruited from the surrounding community, including from fishing and business groups. The Organization of The Tourist Conscious Group is divided into several functions, such as information, promotion, tourism development, guides, financial management, etc. Technical guidance exercises need to be done/given to improve the expertise/professionalism of the Tourist Conscious Group, from technical expertise (swimming, diving for tourist escorts), foreign languages for guides, maintenance of cleanliness and beauty, to the promotion of the area and tourist attractions. The government, in this case, the Tourism Office pioneering the formation of the Tourism Conscious Group.

The government also plays another vital role; for example, the Central Government (Ministry of Marine Affairs and Fisheries) assists in snorkeling equipment, BPSPL Makassar

\footnotetext{
${ }^{7}$ BPSPL Makasar 2017.

${ }^{8}$ Ibid,and based on other sources, such as mongabay.co.id.
} 
provides scuba diving equipment assistance, security forces conduct security guard of the area around the whale shark attraction site, etc. Supervision by the Government to ensure that the status of whale sharks as a protected species continues to be kept safe. Coaching by the government is widely needed, considering the Tourist Conscious Group comes from local citizens and is not a pure professional business operator (as applied overseas, Australia, for example). To better understand whale sharks, research by government agencies and outside researchers (universities and NGOs, domestic and international) needs to be given the opportunity.

\section{Conclusion and Recommendation}

Indonesia has a vast geopark potential. Currently having six UNESCO Geoparks, 13 national geoparks, and several aspiring geoparks, Indonesia is continuously working hard to improve its geopark status. Several laws and regulations have been issued for this purpose, and support from the government and other stakeholders is continuously increasing.

The whale shark is a unique mammal, a giant fish whose presence is unknown, but some can be found in Indonesian waters. Whale sharks can become icons for the development of geoparks (especially for the biodiversity aspect) and tourism development. In Indonesia, one of the provinces that have developed this is the province of Gorontalo.

Botubarani of Gorontalo province is an excellent example in Indonesia, where whale sharks are relatively frequent. It so far has been managed with a relatively advanced geopark and tourism approach.

We support and recommend that efforts to develop geo-tourism that put whale sharks as an icon should continue to be carried out in various Indonesian waters where whale sharks often appear. Apart from Indonesia's great potential and the laws and regulations that it has developed, the primary basis for this support is the world's ample support through its international agencies, especially UNESCO, to develop the world's geopark potential as a new direction development.

We learned from Botubarani and other references that tourism activities need to pay attention to the impact on the environment and the whale shark itself. The principles of conservation against whale sharks are essential to apply.

Technically, for an operation of whale shark tourism management, we recommend doing the following things:

- The interaction zone is used only for limited interaction between visitors and whale sharks (keep the distance and avoid direct contact). It is not permissible to do other activities such as fishing. The boats used in the interaction zone have no engines installed.

- The number of visitors (including those interacting with whale sharks) is limited and regulated (not moving much, not shooting using flash, etc.). The nature of whale sharks should not be disturbed (let alone injured) due to their interaction with tourist visitors.

- Tourist activities should not interfere with the preservation and presence of whale sharks.

- Tourists' activities are limited so as not to interfere with the mobility /movement of whale sharks, including from the area of arrival to the interaction zone.

- The addition of tourist attractions is possible but does not interfere with the main area of whale sharks attractions. The addition of public facilities and services can be done in zones outside the whale sharks interaction zone as well as the tourism development zone.

- Tourist activities carried out still provide a sense of security and comfort to tourists 
- Tourism activities carried out still accommodate the fishing activities by local fishermen.

- Whale shark tourism activities and their derivatives do not have an impact on the quality of the surrounding environment, for example by not littering, maintaining cleanliness, etc.

- Food intake of whale sharks continues to be maintained in number and quality, but not excessive.

- The principles of conservation and good interaction with whale sharks must not only be understood by managers and visitors but also socialize widely with the surrounding community.

\section{References}

Badan Pengelolaan Sumberdaya Pesisir dan Laut Makassar, 2017. Hiu Paus di Pantai Botubarani, Gorontalo.

Keever, P. et. al., 2005. Geoparks: Celebrating Earth heritage, sustaining local communities, Episodes: Journal of International Geoscience, 2005; 28(4): 274-278.

Kurniawan, I. et. al., 2017. The Potential of Gorontalo Province as Global Geopark. IOP Conference Series: Earth and Environmental Science, Volume 536, International Conference on Transdisciplinary Approach Research 2017, Universitas Negeri Gorontalo, Indonesia, August 192017

Nugroho, B. et. al., 2020, Status pemanfaatan dan upaya penanganan hiu paus terdampar di perairan Indonesia, Jurnal Kebijakan Perikanan Indonesia, 2020; 12(1): 47-57. 